\title{
The Juridical Overview of Health Quarantine During the Covid-19 Pandemic
}

\author{
Ragil Jaka Utama*), Umar Ma'ruf ${ }^{* *}$ and Sri Kusriyah ${ }^{* *}$ ) \\ *) The Armed Forces' Military Regions IV-Diponegoro, E-mail: ragil.jaka@gmail.com \\ ${ }^{* *}$ Faculty of Law, Sultan Agung Islamic University Semarang \\ ${ }^{* * *}$ Faculty of Law, Sultan Agung Islamic University Semarang
}

\begin{tabular}{|c|c|}
\hline Article & Abstract. \\
\hline $\begin{array}{l}\text { Article History } \\
\text { Received: 2021-09-10; } \\
\text { Reviewed: 2021-11-08; } \\
\text { Accepted: 2021-11-22; } \\
\text { Published: 2021-11-25. } \\
\text { DOI: } \\
\text { http://dx.doi.org/10.306 } \\
\underline{59 / \text { dh.v4i4.17526 }}\end{array}$ & $\begin{array}{l}\text { This study aims to determine the juridical review of quarantine after } \\
\text { the Covid-19 pandemic and find out whether its implementation has } \\
\text { been carried out and implemented in Indonesia. The type of research } \\
\text { used is normative research or library research, its meaning that this } \\
\text { research is based on library sources to discuss the problems that have } \\
\text { been formulated. By examining secondary data by conducting an } \\
\text { investigation of the study including a description of the research } \\
\text { subject. In this study, the data used in this study were secondary data } \\
\text { and primary data. The secondary data used in this study is the law } \\
\text { used in the study, the primary data used is the regulations in } \\
\text { Indonesian legislation that have been set by each local government. } \\
\text { The data consists of books, articles in journals and other media, } \\
\text { including unpublished research and papers related to and explaining } \\
\text { the concepts of quarantine and social distancing during a pandemic } \\
\text { situation. The results of the study explain that the Health Quarantine } \\
\text { Act carried out by the government in protecting the spread of Covid- } \\
\text { 19 has been very well implemented. This is reinforced by Government } \\
\text { Regulation number } 21 \text { of } 2020 \text { which explains PSBB and handling } \\
\text { related to the Covid-19 pandemic. The implementation of this } \\
\text { legislation is the establishment of a Health Quarantine Officer who is } \\
\text { the only person authorized to enforce the law. Further cooperation for } \\
\text { law enforcement at the local government level requires delegation } \\
\text { from the central government, which will be carried out further by the } \\
\text { Minister of Health. }\end{array}$ \\
\hline
\end{tabular}

(C)2021; This is an Open Access Research distributed under the term of the Creative Commons Attribution License (https://Creativecommons.org/licences/by/4.0), which permits unrestricted use, distribution, and reproduction in any medium, provided the original works is properly cited

\section{Introduction}

The first time the emergence of the corona virus case was reported in Wuhan, China, which then spread quickly to Indonesia. The spread of Covid-19 has had a negative impact on health in Indonesia. Indonesia itself has issued regulations containing laws related to the spread of the Covid-19 virus ${ }^{1}$. Determination of a state of emergency that has been issued in Presidential Decree number 6 of 2018 ${ }^{2}$. This

\footnotetext{
${ }^{1}$ Kusriyah, S. (2011). Negara Hukum \& Konstitusi. Semarang. Unissula Press. p. 51

${ }^{2}$ Act No. 6 of 2018 concerning Health Quarantine
} 
regulation contains a policy that has been implemented to overcome the spread of Covid-19 on a large scale ${ }^{3}$.

The Covid-19 pandemic is a virus that belongs to the dangerous category. The spread of Covid-19 is very fast spread from one person to another. Symptoms that appear in humans usually cause respiratory tract infections, ranging from the common cold to serious diseases such as Middle East Respiratory Syndrome (MERS) and Severe Acute Respiratory Syndrome (SARS). The disease is spread from person to person through the respiratory tract from coughing and sneezing. Various groups are still studying the corona virus which is seen from various aspects ranging from aspects of transmission to aspects of treatment. At least until now, there are two factors that cause the corona virus to spread quickly, namely: First, because Covid-19 is a new disease, so humans do not have immunity to the SARS-COV-2 virus. Second, There is no vaccine or cure yet. Currently, researchers around the world are still vying to find a vaccine and a cure. Efforts made by various groups in many countries in the context of controlling the corona virus are expected to be able to produce the right research products so that the corona virus can be handled immediately ${ }^{4}$.

In addition to the regulations issued, the government's policy carried out in Indonesia is the lockdown policy. The social distancing policy is also used as a method used to minimize the spread that has been carried out in the Indonesian government system ${ }^{5}$. Reducing activities carried out during the policy will have a positive impact on the community environment ${ }^{6}$. Lockdown policies and social distancing policies have been implemented in various countries affected by the corona virus, some countries have implemented lockdown policies and several other countries have implemented social distancing policies. The difference in determining the prevention of the corona virus is based on the characteristics and level of infection of the corona virus in each country. ${ }^{7}$

The purpose of the research in this paper is to find out the juridical review of quarantine after the Covid-19 pandemic and find out whether its implementation has been carried out and implemented in Indonesia. This research is a normative legal research.

\section{Research Methods}

The type of research used is normative research or library research, meaning that this research is based on library sources to discuss the problems that have been formulated. By examining secondary data by conducting an investigation of the study including a description of the research subject ${ }^{8}$. In this study, the data used in this study were secondary data and primary data. The secondary data used in this study is the law

\footnotetext{
${ }^{3}$ Morens, David M., Gregory K. Folkers, and Anthony S. Fauci. (2019). “What Is a Pandemic?” The Journal of Infectious Diseases; 200:1018-21

${ }^{4}$ Budiardjo, M. (2015). Dasar-Dasar Ilmu Politik. Gramedia Pustaka Tama. Jakarta. p.50

${ }^{5}$ Marsiyem. (2011). Pengantar Ilmu Hukum. Semarang. Unissula Press. p. 33.

${ }^{6}$ Cahyo, D. D., \& Bawono, B. T,. (2021). "A Justice Reform In Consumer Protection In Development Of Financial Technology", Law Develpment Journal, Volume 3(3) http://jurnal.unissula.ac.id/index.php/ldj/article/view/16089

${ }^{7}$ Mahfud MD, Moh. (2013). Politik Hukum di Indonesia Ed.Revision. print.1, Jakarta: Rajawali Pers. p. 20

${ }^{8}$ Bachtiar. (2018). Metode Penelitian Hukum. Tangerang: UNPAM Press, p. 43
} 
used in the research ${ }^{9}$, the primary data used is the regulations in Indonesian legislation that have been set by each local government. The data consists of books, articles in journals and other media, including unpublished research and papers related to and explaining the concepts of quarantine and social distancing during a pandemic situation. ${ }^{10}$ The analytical method used in this study is a qualitative method, which is in the form of a study or an indirect measure, in other words, the conclusions are stated in the form of statements and writings or in other words, descriptive techniques.

\section{Results and Discussion}

\subsection{Health Quarantine Act}

Corona virus has become a pandemic disease that has spread to more than two hundred countries. Indonesia as the country with the highest death toll in Southeast Asia has made various efforts to tackle the corona virus. Social distancing was chosen by the central government as an effort that is considered the best solution to deal with the corona virus. Efforts to contain the corona virus must still be carried out by the government. The implementation of social distancing policies must continue to be carried out as an effort to overcome the corona virus both by the central and regional governments ${ }^{11}$. The driving factors for the successful implementation of social distancing policies need to be maintained, while the inhibiting factors must be found ${ }^{12}$.

Social distancing alone without comprehensive regulations on other types of health quarantine will not be effective. As quoted above in the Theoretical Framework, to be effective, health quarantine must be carried out holistically, including isolation. The existence of this quarantine law is not for the purpose of handling the Covid-19 Pandemic or other types of pandemics, but for all kinds of situations and conditions that:

- There has been an extraordinary public health incident;

- These events are: (1) marked by the spread of infectious diseases and (2) events caused by nuclear radiation, biological pollution, chemical contamination, and foodborne diseases;

- The event has the potential to spread throughout the region or country.

The government will issue the regulation, as it may be needed in the future. This is actually in line with other jurisdictions that health quarantine measures can be taken not only in a pandemic situation but in all kinds of situations where a public health emergency is required. In the Health Quarantine Act and its explanation ${ }^{13}$.

According to the law, a Health Quarantine Officer is an official who is authorized by (through the Minister of Health) to enforce the implementation of the Health

\footnotetext{
${ }^{9}$ Sugiyono. (2017). Metode Penelitian Kuantitatif, Kualitatif, \& R\&D. Bandung : Alfabeta. p. 25

${ }^{10}$ Wilder-Smith, Annelies \& Freedman, D. (2020). Isolation, quarantine, social distancing and community containment: pivotal role for old-style public health measures in the novel coronavirus. Journal of travel medicine. 27. 10.1093/jtm/taaa020.

${ }^{11}$ Dewatana, H., \& Adillah, S. U. (2021). The Effectiveness Of Criminal Eradication On Hoax Information And Fake News. Law Development Journal. Volume 3 No. 3

${ }^{12}$ Akbar, C., \& Cahyani, D. R. (2020). Corona, Investor Cina Kirim Bantuan 40 Ton Alat Kesehatan ke RI. Journal Universitas Sebelas Maret, Vol I (3)

${ }^{13}$ Hafidz, J. (2012). Malfungsi Han \& Upaya Melakukan Rekonstruksi Sistem Hukum Yang Ada Menuju Hukum Yang Melayani. Jurnal Hukum Unissula. Vol XXVIII (2)
} 
Quarantine Law, by carrying out health quarantine measures, both at the Entry Points and in certain areas stipulated by law. Until now, there have been Health Quarantine Officers who have been given the authority to deal with Covid-19 health problems. Given the importance of Health Quarantine Officers and now and in the future, the Minister of Health should consider increasing the number of personnel by recruiting Health Quarantine Officers. Public health emergencies, public health graduates and postgraduates can be recruited to fill the position ${ }^{14}$. The Minister of Health is obliged to ensure that graduates and postgraduates of public health have the required competencies $^{15}$.

One of the health measures to reduce the spread of Corona Virus Disease is quarantine. Quarantine involves restricting the movement of both healthy and sick people with the aim of monitoring ${ }^{16}$ and ensuring early detection of new cases. Quarantine policies are then modified in such a way by various countries ${ }^{17}$. Some apply fully, partially or locally and to a minimum. Indonesia itself modifies it under the name Large-Scale Social Restrictions or PSBB which is enforced per region, either province or district/city based on the severity of the outbreak whose assessment is determined by the central government through the Ministry of Health. ${ }^{18}$

Legal policies as described above are actually common in a country of law. The policies taken are based on legal policies aimed at the benefit of the community. The effort to save citizens from the Covid-19 pandemic is an embodiment of the adage expressed by Cicero, "salus populi suprema lex esto" which means that the safety of the people is the highest law for a country.

As a concrete manifestation of efforts to protect the safety of citizens, save citizens from the Covid-19 pandemic or more general referrals, regulate people's lives so that order is created in an effort to handle the Covid-19 pandemic, a law is needed that contains criminal sanctions to anticipate if other legal functions are lacking. The law that contains criminal sanctions is nothing but criminal law, as a law that has the characteristics of criminal sanctions ${ }^{19}$.

The need for criminal law to achieve the efforts as described above, cannot be separated from the function of criminal law. The function of criminal law itself is actually almost the same as other legal functions in general, apart from being a social control, it also functions as a means to change people's behavior as stated by Roscoe Pound (laws as a tool of social engineering). ${ }^{20}$ The function of law as social control is a normative

\footnotetext{
${ }^{14}$ Ariawan, H., and Maryanto, M. Consumer Protection Against Forced Withdrawal By Leasing Parties In Fiduciary Guarantee. Law Development Journal, volume 3(3) 2021.

${ }^{15}$ Parmet, Wendy E. \& Michael S. Sinha. (2020). Covid-19 The Law and Limits of Quarantine." The New England Journal Of Medicine; (28):1-3, from https://www.nejm.org/doi/pdf/10.1056/NEJMp2004211

${ }^{16}$ Ong Argo Victoria \& Myska. (2021). Doctor's Constributions in Transportation Monitoring During COVID19 Pandemic. KnE Social Sciences, Dubai-Uni Emirates Arab (UEA), 5(1) 2020, 598-618. https://doi.org/10.18502/kss.v5i1.8317

17 Margono, D.(2021). Criminal Law Policy In Law Enforcement Of Sim-Swab Crime. Law Development Journal. volume 3(3)

${ }^{18}$ Muhyiddin. (2020). New Normal \& Perencanaan Pembangunan di Indonesia. The Indonesian Journal of Development Planning, Vol. 240 IV Nomor 2. p. 240.

19 Djauhari. (2013). Hukum Tata Negara Indonesia. Unissula Press. 11

${ }^{20}$ Maerani, I. A. (2018). Hukum Pidana \& Pidana Mati. Unissula Press. Semarang. p., 50
} 
juridical aspect of a community's social life or can be called a definition of deviant behavior and its consequences, such as prohibitions, orders, punishment or compensation. So it is often considered as a tool of social control, where the law is considered to function to determine good and bad behavior or behavior that deviates from the law and provide legal sanctions for bad behavior. ${ }^{21}$

This is because public health is a complex knowledge of health. In the current "emergency" situation, temporary and partial recruitment is possible, as the Health Quarantine Officer is the only person authorized to enforce the application of the law. Otherwise, it will be chaos, because no other authority can enforce the law ${ }^{22}$.

\subsection{Implementation of the Quarantine Law}

The government has issued Presidential Decree No. 11 of 2020 concerning the Covid-19 Public Health Emergency. The decision is the mandate of Article 10 paragraph (1) and paragraph (2) of the Health Quarantine Law which authorizes the central government to determine and revoke health emergencies and determine the entrance and or areas in the country affected by a health emergency by first establishing types of diseases and risk factors that can cause a Public Health Emergency. Health emergencies themselves in the General Provisions of the Act a quo are explained, "public health events of an extraordinary nature marked by the spread of infectious diseases and or events caused by nuclear radiation, biological pollution, chemical contamination ${ }^{23}$.

This authority is a manifestation of the responsibility of the central and local governments in protecting public health from diseases and public health risk factors that have the potential to cause public health emergencies through the implementation of health quarantine as stipulated in Article 4 of the Act a quo. Then in Article 5 it is explained that the central government is responsible for implementing health quarantine at the entrance and in the region in an integrated manner and in implementing the health quarantine the central government can involve local governments. ${ }^{24}$

Regarding the health quarantine at the entrance and in the territory, it is stated in Article 15 paragraph (1) of the a quo Law, "Health quarantine at the entrance and in the territory is carried out through observation of diseases and public health risk factors for transportation means, people, goods and / or the environment, as well as responses to public health emergencies in the form of health quarantine measures. In paragraph (2) it is stated that the health quarantine measures as referred to in paragraph (1) are in the form of:

- Quarantine, isolation, vaccination or prophylaxis, referral, disinfection and/or decontamination of people as indicated.

- Large-scale social restrictions.

\footnotetext{
${ }^{21}$ Lamintang, P.A.F. (2017). Dasar Dasar Hukum Pidana Indonesia. Yogyakarta: Deepublish. p. 23

22 Widjaja, G. (2020). “Bagaimana Melaksanakan Pembatasan Skala Berskala Besar.

${ }^{23}$ Ghozali, M., \& Ispriyarso, B. (2021). Online Arbitration in E-Commerce Dispute Resolution During the Pandemic Covid-19. Jurnal Daulat Hukum. volume 4(3)

${ }^{24}$ Dahlan, A. (2011), Hukum, Profesi Jurnalistik \& Etika Media Massa. Jurnal Hukum Unisula, Vol XXV, No

1. https://www.neliti.com/id/publications/12279/hukum-profesi-jurnalistik-dan-etika-media-massa
} 
- Disinfection, decontamination, disinsection, andf or deratization of transportation means and goods.

- Health, security and control of environmental media.

The Health Quarantine Law allows Health Quarantine Officers to work closely with the Indonesian National Police and need their help and cooperation ${ }^{25}$. To that end, the Minister of Health draws up and signs a Memorandum of Understanding with the National Police Chief to regulate how they will cooperate and deal with law enforcement and enforcement ${ }^{26}$. The Health Quarantine Law also opens the possibility for local governments to be involved in health quarantine measures, thus enabling the Minister of Health and the National Police Chief to also cooperate with the local Satpol PP to delegate or distribute this authority for the implementation of the Law, in accordance with its competence based on other applicable laws and regulations, especially those related to Act No. 23 of 2014 concerning Regional Government ${ }^{27}$.

Quarantine implementation requires the use or creation of appropriate facilities where people are physically separated from the community while being cared for. Places that can be used for quarantine include hotels, dormitories, other group facilities, or contact homes. Regardless of the location, an assessment must be made to ensure that the appropriate conditions are met for safe and effective quarantine. Facilities for quarantined persons must be inclusive of persons with disabilities and address the specific needs of women and children. For home quarantine, consider using natural ventilation by opening windows if possible and safe ${ }^{28}$.

The implementation of quarantine in the region, namely PSBB by the Regional Government can be carried out after being determined by the Minister of Health by taking into account the provisions as stipulated in the Health Quarantine Law. Regional governments that wish to implement PSBB are required to submit a proposal to the Minister of Health. Furthermore, the Minister of Health in determining the PSBB takes into account the considerations of the Chief Executive of the Task Force for the Acceleration of Handling Corona Virus Disease 2019 (Covid-19). On the other hand, the Chief Executive of the Task Force for the Acceleration of Handling Corona Virus Disease 2019 (Covid-19) may propose to the Minister of Health to establish PSBB in certain areas and if the Minister of Health approves the proposal then the regions in certain areas are obliged to implement PSBB. ${ }^{29}$

\section{Conclusion}

The results of the study which explain that the Health Quarantine Act carried out by the government in protecting the spread of Covid-19 has been very well

\footnotetext{
${ }^{25}$ Bawono, B. T. (2011). Kebijakan Hukum Pidana Dalam Upaya Penanggulangan Malpraktik Profesi Medis. Jurnal Hukum Unissula, Vol XXV, No 1

${ }^{26}$ Gunarto. (2011). Rekontruksi Paradigma Penegakan Hukum. Unissula Press. p.16.

${ }^{27}$ Richards, E. P., Rathbun, K. C., Brito, C. S., and Luna, A. (2006). The Role of Law Enforcement in Public Health Emergencies; Special Consideration for an All-Hazards Approach. Washington DC: US Dept. Of Justice

${ }^{28}$ Nugroho, F. A., \& Ma'ruf, U. (2021). Implementation Of Complete Systematic Land Registration Services During The Covid-19 Pandemic. Law Development Journal. volume 3(3)

${ }^{29}$ Soedarto. (2006). Kapita Selekta Hukum Pidana. Bandung. Alumni Bandung. p. 20
} 
implemented. This is reinforced by Government Regulation number 21 of 2020 which explains PSBB and handling related to the Covid-19 pandemic. The implementation of this legislation is the establishment of a Health Quarantine Officer who is the only person authorized to enforce the law. The author recommends that the necessary Government Regulations be issued, not only for the current issue of the Covid-19 pandemic but for further events that may occur in the future. The author as an academic and professional believes that universities and professional organizations are willing to support. The author also encourages to empower graduates and postgraduates of public health to practice and implement their expertise in dealing with public health emergencies.

\section{References}

\section{Journals:}

[1] Akbar, C., \& Cahyani, D. R. (2020). Corona, Investor Cina Kirim Bantuan 40 Ton Alat Kesehatan ke RI. Journal Universitas Sebelas Maret, Vol I (3)

[2] Ariawan, H., and Maryanto, M. Consumer Protection Against Forced Withdrawal By Leasing Parties In Fiduciary Guarantee. Law Development Journal, volume 3(3) 2021.

[3] Bawono, B. T. (2011). Kebijakan Hukum Pidana Dalam Upaya Penanggulangan Malpraktik Profesi Medis. Jurnal Hukum Unissula, Vol XXV, No 1

[4] Cahyo, D. D., \& Bawono, B. T. . (2021). "A Justice Reform In Consumer Protection In Development Of Financial Technology", Law Develpment Journal, Volume 3(3) http://jurnal.unissula.ac.id/index.php/ldj/article/view/16089

[5] Dahlan, A. (2011), Hukum, Profesi Jurnalistik \& Etika Media Massa. Jurnal Hukum Unisula, Vol XXV, No 1. https://www.neliti.com/id/publications/12279/hukumprofesi-jurnalistik-dan-etika-media-massa

[6] Dewatana, H., \& Adillah, S. U. (2021). The Effectiveness Of Criminal Eradication On Hoax Information And Fake News. Law Development Journal. Volume 3 No. 3

[7] Ghozali, M., \& Ispriyarso, B. (2021). Online Arbitration in E-Commerce Dispute Resolution During the Pandemic Covid-19. Jurnal Daulat Hukum. volume 4(3)

[8] Hafidz, J. (2012). Malfungsi Han \& Upaya Melakukan Rekonstruksi Sistem Hukum Yang Ada Menuju Hukum Yang Melayani. Jurnal Hukum Unissula. Vol XXVIII (2)

[9] Margono, D. (2021). Criminal Law Policy In Law Enforcement Of Sim-Swab Crime. Law Development Journal. volume 3(3)

[10] Morens, David M., Gregory K. Folkers, and Anthony S. Fauci. (2019). "What Is a Pandemic?" The Journal of Infectious Diseases; 200:1018-21

[11] Muhyiddin. (2020). New Normal \& Perencanaan Pembangunan di Indonesia. The Indonesian Journal of Development Planning, Vol. 240 IV Nomor 2. p. 240.

[12] Nugroho, F. A., \& Ma'ruf, U. (2021). Implementation Of Complete Systematic Land Registration Services During The Covid-19 Pandemic. Law Development Journal. volume 3(3)

[13] Ong Argo Victoria \& Myska. (2021). Doctor's Constributions in Transportation Monitoring During COVID-19 Pandemic. KnE Social Sciences, Dubai-Uni Emirates Arab (UEA), 5(1) 2020, 598-618. https://doi.org/10.18502/kss.v5i1.8317 
[14] Parmet, Wendy E. \& Michael S. Sinha. (2020). Covid-19 The Law and Limits of Quarantine." The New England Journal Of Medicine; (28):1-3, available from https://www.nejm.org/doi/pdf/10.1056/NEJMp2004211

[15] Wilder-Smith, Annelies \& Freedman, D. (2020). Isolation, quarantine, social distancing and community containment: pivotal role for old-style public health measures in the novel coronavirus. Journal of travel medicine. 27. 10.1093/jtm/taaa020.

\section{Books:}

[1] Bachtiar. (2018). Metode Penelitian Hukum. Tangerang: UNPAM Press

[2] Budiardjo, M. (2015). Dasar-Dasar Ilmu Politik. Gramedia Pustaka Tama. Jakarta. p.50

[3] Djauhari. (2013). Hukum Tata Negara Indonesia. Unissula Press.

[4] Gunarto. (2011). Rekontruksi Paradigma Penegakan Hukum. Unissula Press.

[5] Kusriyah, S. (2011). Negara Hukum \& Konstitusi. Semarang. Unissula Press.

[6] Lamintang, P.A.F. (2017). Dasar Dasar Hukum Pidana Indonesia. Yogyakarta: Deepublish.

[7] Maerani, I. A. (2018). Hukum Pidana \& Pidana Mati. Unissula Press. Semarang.

[8] Mahfud MD, Moh. (2013). Politik Hukum di Indonesia Ed.Revision. print.1, Jakarta: Rajawali Pers.

[9] Marsiyem. (2011). Pengantar Ilmu Hukum. Semarang. Unissula Press. p. 33.

[10] Richards, E. P., Rathbun, K. C., Brito, C. S., and Luna, A. (2006). The Role of Law Enforcement in Public Health Emergencies; Special Consideration for an AllHazards Approach. Washington DC: US Dept. Of Justice

[11] Soedarto. (2006). Kapita Selekta Hukum Pidana. Bandung. Alumni Bandung.

[12] Sugiyono. (2017). Metode Penelitian Kuantitatif, Kualitatif, \& R\&D. Bandung : Alfabeta.

[13] Widjaja, G. (2020). "Bagaimana Melaksanakan Pembatasan Skala Berskala Besar.

\section{Regulation:}

[1] Act No. 6 of 2018 concerning Health Quarantine 